\title{
The Development of Problem-Based Practicum Module to Learn Reaction Rate and Basa-Acid Solution
}

\author{
Puspasari $^{1)}$, Indri Astuti ${ }^{2)}$, Dede Suratman ${ }^{3)}$ \\ ${ }^{1)}$ Universitas Tanjungpura, Pontianak, Indonesia \\ E-mail:cupuspa.sari@gmail.com \\ (2) Universitas Tanjungpura, Pontianak, Indonesia \\ E-mail: indribk91@yahoo.com \\ ${ }^{3}$ Universitas Tanjungpura, Pontianak, Indonesia \\ E-mail:d_suratman@gmail.com
}

\begin{abstract}
This study aims to determine the design, stages, and acquisition of student learning by using a practicum-based problem module on the material of reaction rate and acid-base solution. The development model used was a combination of the steps of Borg and Gall development research and Dick and Carey learning model design including needs analysis, design, initial design review, individual trials, revision, developing prototypes, small group trials, revision of finalization and trials field. Data collection techniques are observation, interviews, questionnaires and documentation with data collection tools for learning outcomes tests, observation sheets and questionnaires. Data analysis uses qualitative analysis and quantitative analysis. The results of the study show that the practicum module design is feasible to use, it can be seen from the module evaluation by experts that shows the module has met the eligibility criteria. In addition, field trials showed a positive response to the use of modules. Student learning after using the practicum module shows that students can actively use modules in practical activities. It can be seen from the t-test which shows that the value of $t$ counts $\geq t$ table which means there are differences in learning outcomes before and after using the practicum module. The acquisition of attitude and skill aspects also showed very good results. So it can be concluded that the practicum module in learning the reaction rate and acid-base solution can help students to more easily learn the material of reaction rate and acid-base solution.
\end{abstract}

Keywords: Development; Modules; Practicum; Problem Based

\section{INTRODUCTION}

The reaction rate material and acid-base solution is one of the material that is considered difficult because it has rote characteristics, requires a high understanding of concepts and is very closely related to the problems of everyday life. This material difficulty can be seen in the low acquisition of students. This study aims to develop practicum modules as learning media that can be used independently according to student learning characteristics and material characteristics. So it is necessary to develop media in the form of problembased practicum modules. Through practicum activities, students are expected to be able to prove the theories learned and link the material learned with the problems of everyday life to improve student learning. Suharta (in Purba Friska 2014: 20) states that chemical material has abstract characteristics that require the teacher's ability to make it more concrete. So that it needs proof through a scientific activity, one of which is through practicum activities.

The reaction rate and acid-base solution are material that is closely related to everyday life such as in the field of industry (Purba, 2003: 5). In addition, the basic concepts of reaction rates have a role in the success of students in learning the next material such as chemical equilibrium material. While the use of acid-base concepts such as grouping acid-base 
compounds and calculating $\mathrm{pH}$ are still used in buffer solution materials. So that the success of learning reaction rates and acid-base solutions is very important so that students can easily apply the concepts they learn.

But, chemistry subjects, especially the material of reaction rate and acid-base solution, are considered to be difficult to learn material. It is because one of the characteristics of chemistry is that it contains concepts that are interrelated with one another. Nugita (2016: 1) states that chemistry has a concept difficulty that is high enough to understand. Besides that, the difficulty of the material of reaction rate and acid-base is because this material is theoretical which must be applied in practicum activities.

The assumption that the reaction rate and acid-base material solution are also difficult for students. Panca Bhakti Sungai Raya Vocational High School (SMK). The results of observations conducted on January 8, 2018, showed $26.9 \%$, namely 7 out of 26 students whose learning outcomes reached the criteria of completeness (KKM) which was 75 in the material of reaction rate and $19.13 \%$, namely 5 of 26 students whose learning outcomes reached KKM in acid-base solution material. It shows that the mastery of the reaction rate material and acid-base solution is still low.

Interviews with students from pre-research conducted on 9 January 2018 with six students of Vocational High School and selected heterogeneously. Four students stated that chemistry lessons are difficult because they contain calculations and are memorized. 2 students stated that they liked chemistry because they could prove the theories that existed through practicum activities, but students felt difficulties in the practical process because they did not have special books used for practicum. So it is necessary to develop learning resources designed in accordance with the learning objectives and characteristics of students to facilitate students in proving the theory and understanding the concept of the material.

One way that can help students in proving the theory and understanding the concept of chemistry is learning by using practicum modules. The practicum module contains practicum instructions and procedures that will help in the implementation of the practicum. The advantages of learning with the student practicum module are constructively guided not memorized, so that understanding of a concept is profound and lasting. Also, it can train how to design, conduct experiments and prove hypotheses with problem-solving associated with the real world (Zulfiani, 2009: 104).

One learning model that uses world problems and the process of solving them through practical activities is a Problem Based Learning (PBL) model. According to Sari, Kartika (2015: 16) problem-based learning is a learning approach that uses real-world problems as a context for students to think critically and problem-solving skills. So it can be concluded that the preparation of modules and learning activities to help students understand the concept and practice of reaction rates and acid-base solutions can be done with PBL models.

Based on the explanation above, this has prompted researchers to develop research on the development of learning resources through a problembased practicum media module for learning the reaction rate and acid-base solution of modified students of class XI of Panca Bhakti Sungai Raya Vocational High School that meet the above criteria. Modules will be modified to make it more attractive in accordance with the characteristics of students so that they can be used independently, easily and achieve complete goals. The purpose of the research is to find out how the problem-based module design, how is the problem-based module development and how is student learning acquisition with problem-based practicum modules for learning the reaction rate and the acid-base solution of students.

\section{RESEARCH METHOD}

The research method used was development ( R \& D) by using a combination of Borg and Gall stages and the Dick and Carey development design model consisting of needs analysis, design, initial design review, individual trials, revision, developing prototypes, small group trials, revision and finalization, and field trial trials. Objects in this research are problem-based practicum modules, and research subjects are students totaling 25 people in class XI of Panca Bhakti Sungai Raya Vocational High School in 2017/2018. Data collection techniques in this study are observation, interviews, and documentation. While the measurement technique is in the form of observation sheets, written tests (pretest and post-test) are in the form of 6 questions. The research instrument in the form of observation sheets for assessment of attitudes and assessment of students' skills during practicum, questionnaires used for practicum module assessment by experts and assessment of student responses and test questions that have been validated by one lecturer in Chemistry Education FKIP Muhammadiyah Pontianak and one Chemistry Health teacher Pontianak Reformation with validation results that the instrument used is valid.

The type of data obtained in this development is qualitative and quantitative data. Qualitative data in the form of comments, suggestions or criticism from validators as a basis for revising or improving development products. While the quantitative data is in the form of figures obtained from filling out student response questionnaires and developing product validations using Likert scales $(4,3,2,1)$ and percentage $(\%)$ readability and feasibility. The practicum module validation is carried out by experts 
in their respective fields, namely two people, namely one lecturer and one expert teacher of material to assess the feasibility of the contents of the material, and the questions contained in the module practicum two expert module lecturers to assess the design of the practicum module. Two instructional design experts to assess the module design.

\section{RESULTS AND DISCUSSION}

\section{A. Results}

The following are the findings in the research activities on the development of problem-based practicum modules in the reaction rate practicum and acid-base solution:

1. Design of practicum module development.

The design that has been carried out by researchers uses the Dick and Carey practicum design stages in detail will be explained as follows:

a. Need assessment phase

The findings obtained can be seen in the following Table I:

Table I

Results of Need Assessment

\begin{tabular}{|c|c|}
\hline Rated aspects & Findings \\
\hline $\begin{array}{l}\text { Analyze learning } \\
\text { objectives }\end{array}$ & $\begin{array}{l}\text { Learning objectives refer to the syllabus and curriculum used. The general } \\
\text { objectives to be achieved, namely after the practicum using problem- } \\
\text { based modules are expected to increase student learning from aspects of } \\
\text { knowledge, attitudes and skills }\end{array}$ \\
\hline \multirow[b]{2}{*}{$\begin{array}{l}\text { Conduct analysis of } \\
\text { learning }\end{array}$} & $\begin{array}{l}\text { Curriculum analysis } \\
\text { 1. The curriculum used in Panca Bhakti Sungai Raya Vocational High } \\
\text { School is the } 2013 \text { curriculum, which is a curriculum with a scientific } \\
\text { approach } \\
\text { 2. Assessment refers to cognitive, psychomotor and affective aspects. } \\
\text { 3. This curriculum assessment system essentially supports students to } \\
\text { learn independently by emphasizing the experience of students while } \\
\text { studying. But in reality it is not supported by adequate learning } \\
\text { resources such as limited textbooks specifically for practicum. }\end{array}$ \\
\hline & $\begin{array}{l}\text { Task analysis } \\
\text { 1. Learning specifically the reaction rate material and acid base solution } \\
\text { are not accompanied by practicum } \\
\text { 2. It is not explained whether the learning assignment is carried out } \\
\text { independently or not. So in this study student learning assignments to } \\
\text { study the concept of reaction rates and acid-base solutions through } \\
\text { everyday life problems and accompanied by practicum. } \\
\text { 3. Learning activities are carried out independently by using teaching } \\
\text { materials to be designed. } \\
\text { 4. Knowledge that has been possessed by students through the learning } \\
\text { assignments will be practiced in groups, then presented to prove the } \\
\text { truth of the concepts and solutions of the lessons learned. }\end{array}$ \\
\hline $\begin{array}{l}\text { Analysis of student } \\
\text { characteristics }\end{array}$ & $\begin{array}{l}\text { 1. The ability of students to solve problems is still lacking } \\
\text { 2. Poor learning motivation, can be seen from the results of observations } \\
\text { made on January } 8,2018 \text { at } 07.45-09.15 \text { WIB (Attachment A-1) } \\
\text { 3. Love the direct learning experience (practicum) of chemical material. } \\
\text { 4. The tendency to learn independently and interest in learning through } \\
\text { learning resources that are in accordance with the characteristics and } \\
\text { learning styles of each. }\end{array}$ \\
\hline $\begin{array}{l}\text { Analysis of material } \\
\text { and concepts that will } \\
\text { be taught }\end{array}$ & $\begin{array}{l}\text { The material to be taught consists of two subjects, namely the reaction } \\
\text { rate and acid-base solution studied in class XI. } \\
\text { 1. The reaction rate material consists of several important concepts, } \\
\text { namely: The concept of the rate of reaction in everyday life and the } \\
\text { factors that influence the rate of reaction which include (a) } \\
\text { concentration, (b) temperature, (c) surface area and (d) catalyst . } \\
\text { 2. 2. Acid-base material consists of (a) the concept of acid-base solution } \\
\text { in daily life and (b) identification of acid-base solutions using natural } \\
\text { indicators. }\end{array}$ \\
\hline
\end{tabular}

Based on table 4.1 it can be concluded that the learning carried out in Panca Bhakti Vocational School, in particular, the material of reaction rate and acid-base solution is still not optimal, so it is necessary to do research to improve learning acquisition by developing learning media in the form of problem-based practicum modules designed in accordance with student characteristics and characteristics material.

b. Planning phase

The activity in this planning stage is to include the practicum module design plan, defining the skills developed through the tools that will be produced by first formulating the specific abilities and objectives to be achieved. The results of this stage can be seen in the following Table II:

Table II

Planning Stages

\begin{tabular}{ll}
\hline Rated aspects & \multicolumn{1}{c}{ Findings } \\
\hline Formulate specific & 1. 1. The purpose of learning the reaction rate: \\
goals & 2. After practicing with a practicum module, students are expected \\
to be able to: \\
a. Cognitive goals \\
1) Explain the application of the concept of the rate of reaction \\
in everyday life. \\
2) Analyze the factors that influence the rate of reaction. \\
3) Explain the effect of concentration on the reaction rate. \\
4) Explain the effect of temperature on the reaction rate. \\
5) Explain the effect of surface area on the reaction rate. \\
6) Explain the effect of the catalyst on the reaction rate. \\
b. Psychomotor goals \\
1. Design and carry out experiments on factors that influence \\
the rate of reaction. \\
2. The purpose of learning acid base solutions \\
a. Cognitive goals \\
1) Determine the nature of acid base solution, \\
2) Determine acid base compounds through natural \\
indicators. \\
b. Psychomotor purpose: design and experiment using \\
indicators.
\end{tabular}

Based on Table II above can be concluded in designing a product researchers must have good planning, as for the planning that is done in determining the specific objectives of the practicum, developing test criteria, developing learning strategies and developing and selecting teaching materials to be developed. So that researchers are easier to design practicum modules.

2. The stages of developing practicum modules

a. Writing and preparation of practicum modules

Through the design results of the development of the previous practicum module, then the writing and compilation of modules were carried out. The stages in the preparation and writing of the practicum module in this research are carried out by:

1) Collecting material from various literature as a reference for writing the module content, the collection of literature begins by collecting teacher handbooks and available textbooks in the research location. In addition, the collection of material is carried out through other learning resources such as 
the internet and similar modules related to the same content.

2) Determine the content and sequence of practicum material by (1) identification of field topics, concepts, principles, theories that will be presented in the module, (2) outlining the subject matter into the subsubject matter. It is done with the aim of: (1) so that the material to be presented is relevant to the objectives of the practicum formulated (2) in accordance with the level of development of students.

3) Preparation of practicum activities in accordance with the approach to be used, in this case, is a problem-based practicum activity.

b. Expert assessment (Expert appraisal)

After the writing and preparation of the module are complete, the next phase of the module development is the validation of the module design by experts. The design of the problem-based practicum module will be validated by two media expert lecturers, media experts, two material expert lecturers, and two design experts.

The practicum media validation experts refer to similar findings conducted by Khabibah, namely the assessment criteria starting from the lowest score scores of 1,2,3, and 4 in each aspect. Validation results are detailed as follows:

1) Results of media expert assessment.

Assessment by media experts on practicum modules is carried out on (1) linguistic aspects (2) presentation aspects (3) effects on practicum (4) overall appearance. The results of the assessment of media experts on the practicum module can be seen in Figure 1 below:

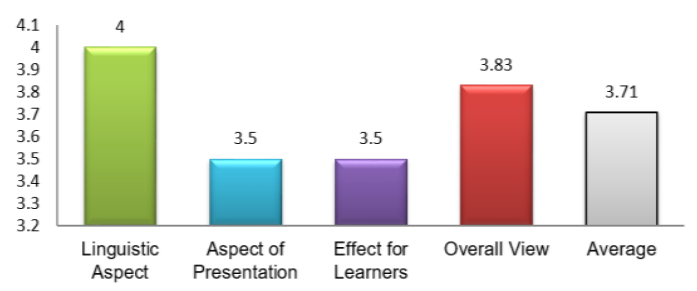

Fig. 1 Practical media validation data by media experts

Based on Figure 1, the results of the validation of media experts showed that the practicum module had a value of 3.60 or greater than 3 . So referring to the validity criteria according to Khabibah concluded that this practicum module was valid from linguistic aspects, presentation, effects to practicum, overall appearance.

2) Results of assessment of material experts

Assessment by experts Material on the practicum module is carried out on (1)
Suitability of the material with KI and KD (2)

Accuracy of the material and examples (3)

Accuracy of dialogue and language (4) Accuracy of evaluation questions. The results of the assessment of material experts on the practicum module can be seen in Figure 2:

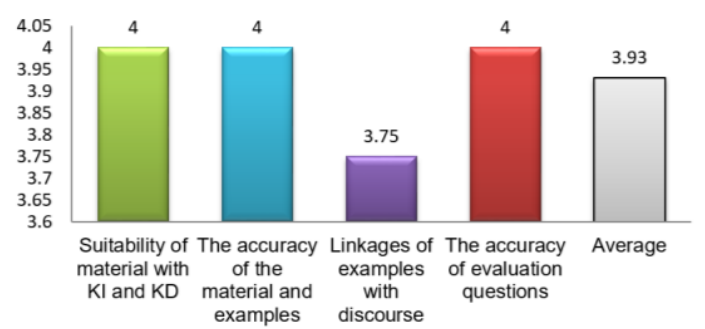

Fig. 2 Practical media validation data by material experts

Based on Figure 2 the results of the validation data of the material experts show that the practicum module has a value of 3.93 or greater than 3 . So that refers to the validity criteria according to Khabibah, it can be concluded that this practicum module is valid from the aspect of material suitability with KI and $\mathrm{KD}$, the accuracy of the material and examples, accuracy of dialogue and language, accuracy of evaluation questions.

3) Results of assessment of design experts

Assessment by design experts on practicum modules is carried out on (1) Completeness of the title (2) Accuracy of the question (3) Accuracy of summary, (4) Suitability of the module with PBL steps and (5) Attractiveness of the physical form of the module. The results of the expert assessment of the designation of the practicum module can be seen in Figure 3 below:

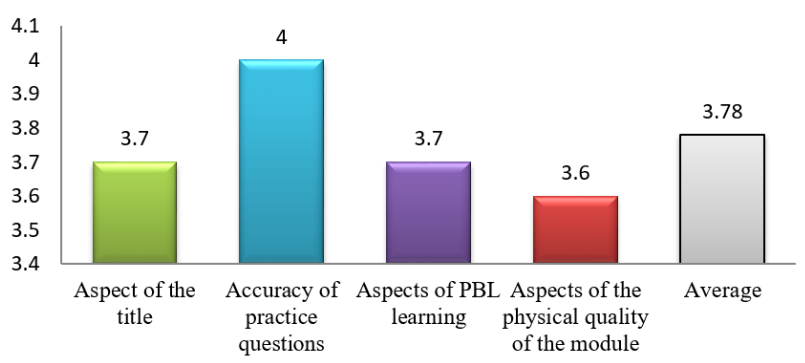

Fig. 3 Expert Assessment Results of The Drafting on Practicum Modules

The practicum module has a value of 3.8 or greater than 3 . So referring to the validity criteria according to Khabibah, it can be concluded that this practicum module is valid from the aspect of material suitability with $\mathrm{KI}$ and $\mathrm{KD}$, the accuracy of the material and examples, the accuracy of dialogue and language, the accuracy of evaluation questions. 


\section{c. Empirical trial}

The next stage of the practicum module development activity is conducting field trials. This trial was conducted with the aim that the module can be easily understood by students. To fulfill the readability of the module, there are several aspects that are carried out, namely:

1) The language factor used must be in accordance with good and correct language rules. Besides that, the level of simplicity of the language used must be in accordance with the characteristics of students.

2) A familiar style of presentation that attracts students when using modules

3) Seeing the level of students' abilities so that the material presented is made so that students are easier to understand.

The module readability test activity was carried out in 3 stages, namely individual trials, small group trials, and large group trials, for some students in class XI by giving questionnaire responses and classroom observations which would later be used as input in revising the product. The implementation of the trial activities is as follows:

1) Observing learning interests and responses from students during class lessons. Students' behavior when following the teaching and learning process can indicate the student's interest in the lesson or vice versa.

2) Provide questionnaires (questionnaires) responses to students after they are given a module. Students will later assess the language used, examples of questions presented, and lack of modules according to the assessment of each student as the subject of the trial.

1) Individual trial (one to one)

The findings during the individual trial implementation are as follows:

a) The trial was conducted on July 24 at 7:00 a.m. to $7: 45$ p.m. located at Panca Bhakti Sungai Raya Vocational High School

b) The subject of the trial consisted of 3 students of class XI PHARMACEUTICAL Selection of the test subjects was carried out in a random way consisting of 1 student with high ability, one student with moderate ability, one student with lower ability.

c) Results of student responses after practicum using the module can be seen in Figure 4:

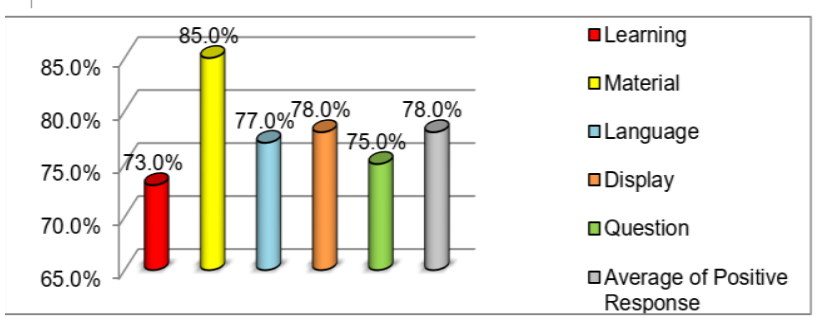

Fig.4 Student Response Results After Practicum Using The Module

Figure 4 shows the response of students on aspects of practicum $73 \%$, material $85 \%$, language $77.0 \%$, display $78 \%$, questions $75 \%$ and the results of the average positive response of students to the practicum module is $78.0 \%$. Based on the data analysis, referring to Khabibah it can be concluded that the practicum module still needs to be revised on the aspects of appearance, and questions before the field group are tested.

2) Small group trials

The findings obtained in the small group trial are as follows:

a) The trial was held on July 25, 2018, at 6:45 a.m. - 8:45 p.m. located at Panca Bhakti Sungai Raya Vocational High School.

b) The subject of the trial was six students of class XI Pharmacy. The selection of test subjects was carried out in a random way consisting of 2 students with upper capability, two students with moderate ability, two students with lower ability.

c) Results of the questionnaire's small group student response to the module can be seen in Figure 5 following:

\begin{tabular}{|ll}
$86.0 \%$ \\
$84.0 \%$ \\
$82.0 \%$ \\
$78.0 \%$ \\
$76.0 \%$ \\
$74.0 \%$
\end{tabular}

Fig. 5 Student Response Results When Test

Figure 5 shows the response of students on the aspect of practicum $82 \%$, material $85 \%$, language $83 \%$, display $78 \%$, questions $82.5 \%$ and the results of the average positive response of students to the practicum module is $82.1 \%$. Based on this analysis it can be concluded that it still needs to be revised practicum modules, especially on aspects of the display before being used for large group trials.

3) Test Large Groups

The trial was held on July 25, 2018, at 07.00 - 8.30 WIB at Panca Bhakti Sungai Raya Vocational High School. The subject of the trial was 21 students of class XI 
PHARMACEUTICAL. The selection of test subjects was carried out in a random way consisting of 7 students with upper ability, seven students with moderate abilities, seven students with lower ability.

a) Observations when practicum shows practicum modules can be used as teaching materials in practical activities using problem-based strategies.

b) The results of the questionnaire response of a large group of students to the module can be seen in Figure 6 below:

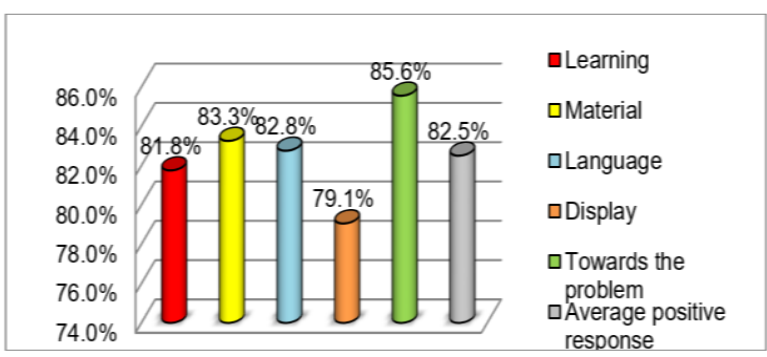

Fig. 6 Results of student responses during large group trials

Figure 6 shows students' responses on $82 \%$ practicum, $83 \%$ material, $82 \%$ language, $79 \%$ view, $86 \%$ problem and the average student positive response to the practicum module is $82.50 \%$. Based on the analysis concluded that as a whole, the practicum module is very good and can be used in the field testing phase.

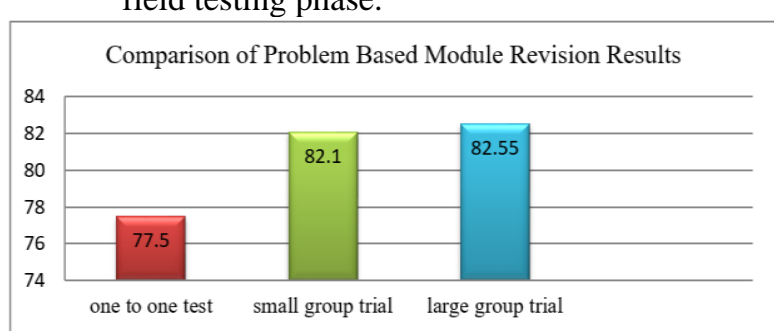

Fig.7 Comparison of the results of problem-based module revisions

Figure 7 shows that there has been an increase in the revised value, that is from the results of the trial one to one $77.5 \%$ and then revised, followed by a small group trial has increased to 82.1 and continued with a large group test of acquisition value of 82.55. Based on the data analysis it was concluded that the problem-based practicum module was getting closer to the perfect stage and feasible to be used in the practical process in the classroom.

4) Test the field group

The findings during the field group trial implementation are as follows:

a) Field group trials carried out on 26 and 31 July 2018 at 07.00-09.15 WIB at Panca Bhakti Sungai Raya Vocational High School. b) The subjects of the field group trials were students of class XI Pharmacy 2 with a total of 25 students.

c) The implementation of practicum activities during field trial trials was carried out by referring to the results of improvements from the practicum scenario during the large group trials. With this, it is expected that during the implementation of the module practicum, using the problem-based practicum can be implemented properly.

d) The results of the response of the students of the field group trial subjects to the interest in practicum using the module can be seen in the following Figure 8:

\begin{tabular}{|ll}
$88.0 \%$ \\
$87.0 \%$ \\
$86.0 \%$ \\
$85.0 \%$ \\
$84.0 \%$ \\
$83.0 \%$ \\
$82.0 \%$ \\
$81.0 \%$
\end{tabular}

Fig. 8 The results of the students' responses when testing the field group

Figure 8 shows the average positive response of students after practicum using a module that is $84.8 \%$ or greater than $70 \%$. So it was concluded that the results of this calculation according to Khabibah, the problem-based practicum module could be used and interesting for students in chemistry practicum activities in the classroom.

3. Student learning after the use of modules

a. Knowledge

The preparation of the "problem-based practicum" module in this study aims to help students overcome difficulties in practicum activities ranging from poor responses to practicum activities and difficulties in understanding the concept of reaction rate material and acid-base solutions. During practicum activities, using the student module provides good response, in this case, students actively learn and understand the modules provided. Students do not hesitate to ask questions related to the contents of the module.

1) Students 'understanding of the concept of reaction rate and acid-base solution has been good enough. It can be seen from the results of measuring students' level of understanding using test questions. Measurement of students' level of understanding is done using pretest and posttest.

2) Measurement of the level of understanding is carried out on students of class XI Pharmacy 2 of Panca Bhakti Sungai Raya Vocational 
School with a total of 25 students. The results of the pretest and posttest can be seen in the following table:

Table III

The Acquisition of Learning Outcomes for Large Group Trial

\begin{tabular}{cccc}
\hline Test subjects & Pre test & Post test & Difference \\
\hline Total Score & 831 & 2116 & 1285 \\
Average & 33.24 & 84.64 & 51.4 \\
\hline
\end{tabular}

Based on Table III shows that the average value of student learning outcomes before using the practicum module 33.24 , while after practicum is 84.64 with a difference of 51.4. A total of 21 students scored above 75 and four students scored below 75. Based on the data analysis, it was concluded that there was an increase in good learning outcomes because more than half of students obtained scores above the KKM.

The average increase between learning gains before and after practicum using the module can be seen in following figure:

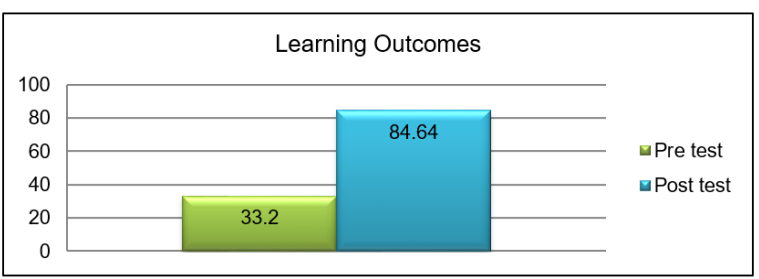

Fig. 9 Comparison Diagram of Learning

Outcomes for Large Group Trials

Based on Figure 9 shows the pretest average value is 33.2 while the posttest value is 84.64. So it can be concluded that the use of reaction rate modules and acid-base solutions can improve students' understanding of problemsolving and the concept of reaction rates and acid-base solutions.

3) t-test of two paired samples

The two paired sample t-test is an analysis to test differences in paired sample learning outcomes. The sample in question is the pretest and posttest results of 25 people from different classes. The results obtained th $=20.64$, compared with t table in df $n-1(25-1)=24$ is 2.078 . Then th $=$ $20,64>$ tt $\alpha 0,05=2,078$. This means that there are differences in learning outcomes that result between the pretest and posttest scores of students.

2. Attitude
Attitude assessment is carried out during the research process. Some findings related to student learning acquisition in this study are:

a. Assessment is carried out two times during teaching and learning activities in the classroom and carried out by two observers.

b. From the assessment of students 'attitudes, each meeting obtained results that students' attitudes experienced a good improvement. The average value of each aspect shifts 3.6.

c. Increased results that student attitudes can be seen in Figure 10 below:

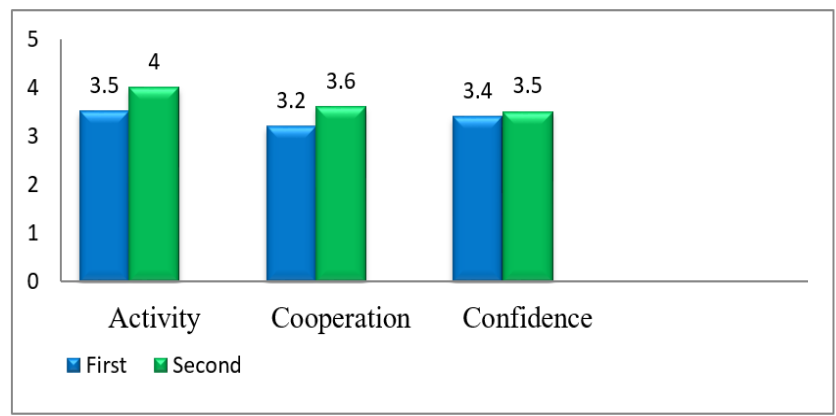

Fig. 10 Results of Student Attitudes Assessment Based on graph 4.10 it was concluded during the practicum process from meeting one Until the second meeting, overall there was an increase in each aspect. So practicum activities using problem-based modules can increase student activity, cooperation and confidence with a very good average rating.

3. Skills

Assessment of student or psychomotor skills is carried out when students conduct practical activities. The findings obtained are;

a. Skills assessment is carried out by two observers. Skill assessment includes practicum preparation activities, practicum processes and after completing the practicum.

b. The results of the assessment show that students are skilled in practicum with an average value of each aspect as much as 3.5, which is an excellent category.

c. Data from the assessment of student skills can be seen in the following Figure 11:

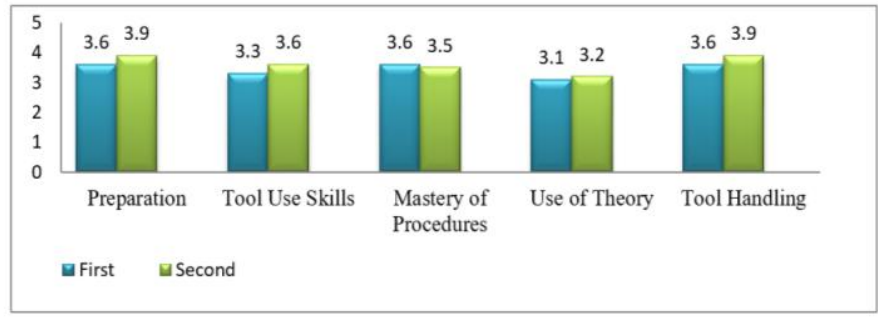

Fig. 11 Results of Assessment of Student Skills Based on Figure 11, it was concluded during the practicum process from the meeting of one to two meetings; overall there was an 
increase in each aspect of skills. So practicum activities using problem-based modules can improve students' skills in the use of tools, mastery of procedures, use of theory and handling of tools is very good.

\section{B. Discussion}

\section{Design of practicum module development}

The design of the practicum module development is an archipelago study conducted to obtain the information needed before carrying out development activities, or in other words, the design of the practicum module development is a preliminary analysis carried out as a form of reference in planning practicum module writing activities. In this study, the design of practicum module development includes front and analysis (analysis of curriculum and learning resources), learner analysis (analysis of student characteristics), task analysis (task analysis), concept analysis (analysis of concepts to be taught), specifying instructional objectives (formulating practical purpose).

As has been explained in the findings of the research results, the results of the study on the development design begin with conducting an initial diagnosis of the curriculum, and the learning resources used. It is intended so that later the development activities carried out can increase learning acquisition because the analysis is carried out on the competencies to be achieved. Will later all the competencies contained in the curriculum can be provided with teaching materials. Through the findings of the research conducted, information was obtained that the use of the 2013 curriculum in Panca Bhakti Sungai Raya Vocational High School was not supported by adequate learning resources. So that the achievement of each competency in the chemical practicum, in particular, cannot be achieved well.

The preliminary study carried out later in the design of module development is to analyze the characteristics of students. It is important because to overcome the problems that arise from the results of curriculum analysis is to produce learning resources that are in accordance with the characteristics of students, as stated by Mulyatiningsih (2011,196). Teachers must recognize the characteristics of students who will use teaching materials. Based on previous research findings it can be concluded that the characteristics of students in learning chemical material are a low level of understanding of chemical material, new learning experiences of chemical material, tend to study independently and the most prominent are differences in learning styles of each student. Through this information, the preparation of teaching materials to be carried out must use simple language and be adapted to the learning styles of students who tend to be individualistic.
Next, is to analyze student learning tasks and adjust the content of the material to be given, these two things are important components in preparing practical activities. The suitability of the material and learning assignments provided will make it easier for the teacher in compiling teaching materials that will help students in fulfilling the expected competencies. The steps taken in analyzing this material are collecting and selecting relevant material and systematically rearranging it. The material chosen is the material of reaction rate and acid-base solution because it corresponds to the background that has been submitted previously.

Through a series of activities that have been carried out previously, the last activity carried out in the development design is to formulate the objectives of the practicum to be achieved. The purpose of the formulation of the objectives of the practicum carried out before writing the teaching material is so that the researcher does not deviate from the original goal at the time of writing the teaching material. In addition, the goal of practicum is to become a reference in formulating test indicators that will be used in measuring the success of learning using instructional materials that have been compiled.

Test indicators that will be used to measure the success of learning after using the module in this study will be formulated in the form of questions on pretest and posttest questions. The standardized test consists of 6 questions (item B-2, page 152), the selection of tests in the form of essay choices is intended so that students can answer the questions given in accordance with the knowledge that has been built individuals when practicum activities are carried out. The questions that have been designed are then validated by two validators. One chemistry lecturer and one chemistry teacher. The results of the assessment by the validators said that the problem must be corrected again, including repairing the grid on the questions about numbers 1 and 2, the language used in making problembased questions must use standard language. Then from the results of the evaluation by the validators, the problem is corrected and submitted back to the validator so that it is validated based on the results of the improvements that have been made so that the questions that will be used are valid or feasible to use (Appendix C2 Page 178).

The final conclusion of the studies on the design of the practicum module development that is carried out is to plan the writing and preparation of the reaction rate practicum module and acidbase solution. Because it is in accordance with the opinion of Daryanto (2013: 23), planning in preparing the writing of the module is very important because, with good planning in writing the module, the resulting module will have a high 
level of readability, as well as the depth of the material in accordance with the level of ability of students/training participants.

The planning stage for writing module teaching materials involves experts. Experts, in this case, are subject matter experts, practicum experts or at least people who are knowledgeable and experienced in the field of practicum and curriculum methodologies, as well as media experts or at least people who are knowledgeable about practicum media. It is through this planning stage that the practicum module can be prepared and developed at the next stage.

The difficulties during the implementation of designing the practicum module development are the limited time in conducting analyzes related to the information needed by the researcher, the limitations of the observer's ability when making observations on the characteristics of students, the limited facilities and practical support facilities and the limited ability to sort out the material. Relevant and systematic rearrangement of material.

2. Phase of developing practicum modules

The practicum module development phase is an activity carried out to compile, write, and test the readability and feasibility of the initial design of the practicum module. Through planning when designing the module development, the module writing is done by referring to the formulation of the practical objectives, the characteristics of the students and the composition of the material that has been formulated previously. It is done so that during the writing and preparation of the module the researcher does not deviate from the objectives that have been formulated.

During the preparation of the module, researchers consulted with chemical material experts Purwanti Suci, S.Pd and the practicum expert Hambali, S.Pd. It is done so that the contents of the practicum module have a level of legibility that is appropriate to the characteristics of students and expected material so that later during the use of modules when practicum activities are carried out there are not many difficulties experienced by students as users of the practicum module.

The design of the practicum module that has been compiled later will be validated by experts to assess the feasibility of product design. Product validation will be carried out by six experts consisting of 2 expert material lecturers to assess the feasibility of the content, and the questions contained in the module, two media expert lecturers to assess the module design. Whereas for product design assessment, RPP and response questionnaire will be carried out by two design expert lecturers
The assessment carried out by experts is done directly with the face-to-face process between researchers and experts, this is done so that during the assessment process, comments and suggestions given can be directly accepted by the researcher as a practicum module designer so that when the practicum module design improvement can be properly carried out follow comments and suggestions that have been given. The results of the validation carried out in the initial module design show that the module has sufficient validity and feasibility. In the sense that the initial design of the chemical module is feasible to be tested on students as field users of the practicum module, but with a note that the module must be revised according to the input and comments that have been given.

Through the results of the improvement after the assessment of the practicum module design, the next step that will be carried out by researchers is field trials. The purpose of conducting this field trial is to find out the level of module readability seen from the module's ability to assist the practicum process. In accordance with Mulyasa's opinion in Purnomo et al. (2013: 60) learning resources are all things that can facilitate students in obtaining some information, knowledge, experience, and skills. In addition to knowing the readability level of the practicum module. This field trial is also intended to find out the students' positive response to practicum activities and the contents of the module. Because essentially the module should be able to provide a positive response to student learning motivation.

The first field trial was an individual trial to find out how the initial design of the problembased practicum model. This trial was conducted on three randomly selected students according to their learning abilities, namely students with high ability, moderate ability, and lower ability. The purpose of this random student selection is to avoid the subjectivity of researchers in the selection of research objects. Based on the results of trials conducted several aspects of the module design need to be improved especially on aspects of material, language, and appearance. It shows that the language and content of the material used in the module must be further simplified according to the characteristics of students. Improvements to the components of the contents of this module are very important because it is a form of ease of use of modules or what is called user-friendly characteristics.

Through the results of improvements that have been made during individual trials. The next step is a small group trial. As with the selection of individual trial subjects, the trial subjects were chosen randomly but with a different number of trial subjects, namely six 
students. The researcher then revised based on the results of the response questionnaire on the smallscale test, after completing the revision the researcher continued at the large-scale test stage with 22. But at this stage of the trial in addition to knowing the readability of the student module the researcher also conducted a scenario of practicum activities. Adjust the use of practicum modules with practicum scenarios in the classroom. The steps taken by the researcher before developing a practicum scenario are as follows:

a. Study the learning resources that will be used by students to adjust the material content contained in the practicum module.

b. Determine the time, equipment or tools that will be used in the practicum.

c. Writing down the steps that will be carried out in the practicum process in accordance with the stages of the practicum planned in this case is the stage of practicum with a constructivist approach.

d. Write down complete practical steps.

e. Write a plan for evaluating learning activities.

f. Criteria for success of assessment results can be detailed in detail and include three copies, namely cognitive, affective, and psychomotor.

The practicum scenario that has been compiled is said to be important because it is a story sequence compiled by a teacher so that a practicum event occurs as desired. Previously, researchers conducted preparations which included preparation of teaching materials whether the teaching materials could be used during the teaching and learning process. Then student conditioning is done by preparing students before starting the practicum which refers to the problem-based practicum scenario

During the large trial, the scenario or the practicum steps that have been compiled must be in accordance with the conditions of the material content submitted and the time allocation used or in other words the practicum scenario used must be with real conditioning of the current practical situation in the classroom. It is done so that when the practicum module is used with real estate conditions, there is no obstacle to the suitability of the module with the stages of practicum activities in the classroom. Referring to the opinions of Susilana and Riyana, Nasution in Purnomo (2013: $60)$ suggests that the module is a complete unit consisting of a series of learning activities arranged to help students learn independently in achieving a number of goals that are formulated specifically and clearly, so the use of modules besides being able to be used independently, it must be in line with a practicum scenario because it is a unit of unity in practicum activities.
The results of the large group trial show that the practicum module can be used as teaching material in practical activities using a studentoriented approach. During practicum activities the use of modules can help students in understanding the concepts learned, through practicum activities, it's just that some shortcomings in the use of modules in group practicums are, the need to adjust the practicum time with the stages of learning activities in the module. Learning activities in the module should be followed by the preparation of appropriate time.

As for the response given by students as much as $82.55 \%$ is a positive response. It shows that the results of improvements to the simplicity of the material and language carried out after the previous individual trials provided good results for the subjects of this small group trial. Or in other words, one of the important components of using modules is to provide learning motivation that is good for students.

The final step in the development of the practicum module is the field group trial. During the implementation of this field group trial activity, the implementation was the same as the large group trial; it was only done on a different subject with a larger number or in other words carried out on the real conditions of a classroom learning environment. Each phase of practicum activities carried out refers to the results of improvements from the phases of the practicum that have been tested before with the hope that there will be no obstacles during the implementation of this trial. The steps taken in this activity refer to problem-based practicum. The stages are (1) The first stage of student orientation on the problem. At this stage, students are asked to read discourse related to daily life in the practicum module. (2) The stage after students read and understand the problems presented students must find additional information about the problems presented to get a solution or a temporary solution to the problems presented. Additional information is also useful to increase students' knowledge about existing problems. Students write problem solving or hypotheses obtained from various sources on the problems presented. This activity trains students to be active in learning activities so that students can construct knowledge independently based on information obtained. (3) The third stage students do proof of solving problems or hypotheses that have been compiled. Proof is done through practicum and group discussions. Students share tasks in practicum activities. Students are very enthusiastic and active in practicum. Practicum activities carried out to make students easier to understand and find answers to the problems presented because students are directly involved 
in practicum activities. The results of the practicum activities are then recorded as practicum data. Students conduct group discussions to discuss the results of the practicum obtained and then adjusted to the information that has been obtained. Practical data that has been processed and discussed is then presented in front of the class at the next meeting. (4) Develop and present the work. This stage students present the findings of the practicum that is carried out in front of their class. (5) Analyze and evaluate the problem-solving process. At this stage, the teacher provides input and reinforcement about problemsolving delivered by each group and together with students concludes about the material that has been learned. Student learning outcomes show positive results; this shows that PBL's approach to learning provides good learning outcomes.

During the field trial, there were no obstacles to the practicum scenario implementation that had been prepared previously. During the implementation of the constraints found only related to the allocation of practicum time this is because when the field group trials are needed more time in conditioning students when participating in practicum activities, including when the formation of student learning groups, preparation of practicum materials and materials used, activities practicum and reflection on students' performance when expressing their opinions regarding the material that has been delivered. While the response given by the subject of this trial is $84.80 \%$ positive response or in other words during the practicum using practicum modules students have good learning motivation.

3. Student learning after the use of modules

The use of practicum based on reaction rate problems and acid-base solutions is basically intended to assist students in facing the difficulties of reaction rate practicum and acidbase solutions. Overall when viewed from the observations during the practicum using the student module provides good response, in this case, students actively learn and understand the discourse in the module. Students do not hesitate to ask questions related to the contents of the module, other than that students actively carry out practicum in accordance with the procedures and practicum designs contained in the module. Students also bravely convey the ideas/understandings they have gained after practicing the material of reaction rate and acidbase solution by presenting the results of their group practicum in front of the class and willing to accept input from other students regarding the deficiencies and conceptual errors that have been learned.
Acquisition of learning outcomes aspects of knowledge showing success in the use of modules is an increase in the level of students' understanding of the material being studied. It can be seen through the results of lab tests and given posttest; the test will be used to measure the extent to which students have solved the problem in the material of reaction rate and acid-base solution. The instrument used for each student is the same between one student and another. Questions have been prepared based on indicators of students' thinking skills that are in accordance with the problems faced in daily life.

The test results given to students aim to see differences in student learning outcomes before and after using the practicum module. The difference in the acquisition of learning outcomes shows an increase in students' problem-solving in the material of reaction rate and acid-base solution. The acquisition of student learning outcomes before practicum with an average of 32.24 , while after practicum is 84.64 with a difference of 51.4. Of the 21 students, 15 students obtained a test score of $\geq 75$. It showed that the students' ability to understand the concept of reaction rate and acid-base solution was good enough. While as many as eight people obtained a test score of $\leq 75$, which means that the ability of students in solving problems contained in the module is still not good. It can be caused by the ability of students who tend to require a long time in understanding the concept being taught, or in other words; it needs to be repeated in stages in understanding the material of the reaction rate and the acid-base solution contained in the module.

In addition to calculating the average pretest and posttest, the researcher also conducted a t-test to test the differences between the two pretest and posttest student scores. The results obtained based on the calculation is the value of $\mathrm{t}$ count> table (8.36> 2.078) then Ho is rejected, and $\mathrm{Ha}$ is accepted, meaning that there are differences in results between before and after learning using a problem-based practicum module in the reaction rate practicum and acid-base solution.

Learning outcomes on the attitude aspect are done twice. Attitudes observed include aspects of neatness, liveliness, curiosity, cooperation, and confidence. The average percentage of students' attitudes shows positive results with an average of more than 3.6. The results obtained can be seen as the value of the attitudes of students from the initial meeting to the last meeting always experienced an increase in all aspects according to the data in Figure 4.9. In general, the neatness aspect is already good from the start, but from the initial meeting to the next meeting students also still have good changes. 
Students are neater in dressing and styling their hair.

The aspect of student activity also increases, students are enthusiastic in participating in the practicum process and eagerly seek additional information about existing problems or material presented by the teacher. PBL's integrated learning process makes students active in analyzing problems, conducting small discussions to solve problems, collecting and processing new information, drafting new knowledge concepts and communicating misunderstandings about existing problems. The activeness of students in the PBL process has a positive effect on the success of the learning process. The PBL approach is effective in increasing student curiosity. Students in studying a problem always seek information related to the problem. Students sometimes ask the teacher, read related books or look for additional information on the internet. Students always try to find a solution to the problems that exist even though later the solution is ultimately not right.

Learning outcomes on aspects of skills are observed during the practicum. The average percentage of students' skills at the time of practicum showed positive results, namely with an average of more than three aspects, 3.5 , with very good criteria based on the data in Figure 4.10. Students are skilled in conducting practical preparation activities, in addition, students are also skilled in using tools, and following practicum in accordance with the procedures in the practicum module. After completing the practicum, each group cleans the tools that have been used and stores them in the tool cabinet provided.

Practicum module in research is basically used as a substitute for textbooks or textbooks where students do not have it yet, this module is done with language as easy as possible so that the module can support students in solving their problems or commonly known as constructivism theory so that mastery of students' concepts will be better mastered because the student himself who invented the concept and built it.

Understanding in chemistry practicum will be more meaningful if it is built by students themselves. Therefore, understanding ability cannot be given by force, meaning that concepts are given by the teacher, and when students forget the student cannot properly solve problems in chemistry. The module in this study has a positive impact proven from the activities of students in the classroom, when asked randomly and when given questions by the teacher, students can explain important concepts in the rate of reaction and acidbase solutions.
In addition to increasing the understanding that the students' positive response to the practicum using the practicum module shows that the practicum module preparation is in accordance with the characteristics of students. Modules can effectively motivate students in learning because they are familiar to students. It is in accordance with the opinions expressed by Daryanto and Dwicahyo, (2014: 25) that: Modules should also meet the rules of user-friendly or friendly/familiar with their use. Each instruction and information disclosure that appears to be helpful and friendly with its use, including the ease of the user in responding and accessing as desired. The use of simple language, easy to understand, and to use commonly used terms, is one of the user-friendly forms.

\section{CONCLUSIONS AND SUGGESTIONS}

\section{A. Conclusions}

Based on the results of research that has been done, in particular it can be concluded that the module development design is used as a reference in developing problem-based practicum modules including analysis of learning objectives, analysis of learning, analysis of student characteristics, determining specific objectives and planning to analyze the curriculum and needs analysis for module development. The stages of developing practicum modules are used to develop practicum modules that are suitable for use. Includes writing the contents of the module, validating the contents of the module by experts and conducting field trials to obtain the response and effectiveness of the practicum module. Whereas student learning acquisition using problembased practicum is effective towards improving student learning outcomes. The domain of attitudes and skills shows very good results, and the realm of knowledge is seen from paired t 2 test which shows that the t-count value> t-table so that there are differences in learning outcomes between before and after using problem-based practicum modules in learning reaction rates and solutions acid base.

\section{B. Suggestions}

Development research is carried out to produce a new product or perfect an existing product, one of which resulted from the development of a chemical practicum module. Based on the results of research and development, here are some suggestions that researchers can convey.

1. Suggestions according to the design of the practicum module development

a. For other research can be a reference for further research on the development of problem-based practicum modules.

b. For the next researcher, more and more recent literature is needed to develop material media teaching problem-based lab modules.

c. For other researchers who want to research problem-based practicum modules can 
conduct research using different strategies and materials.

d. For other researchers, it is necessary to be careful in designing and developing this practicum module, one of them is when analyzing student characteristics so that the modules produced are in accordance with the characteristics of the student.

2. Suggestions according to the stages of the problem-based practicum module

a. For other researchers, it can be used as literature on the stages of module development with a combination of Borg and Gall and Dick and Carey

b. For other researchers can carry out the development stage until the dissemination stage so that modules can be used in other schools.

3. Suggestions according to student learning.

a. For teachers of chemistry subjects, the problem-based practicum module can be used as a practicum media because it can increase student learning acquisition.

b. For other researchers, a problem-based practicum module can improve student learning on aspects of attitudes, skills, and knowledge in a wider sample.

c.

\section{REFERENCES}

Borg. W.R dan Gall, M.D. 1983. Educational Reasearch: An Introduction. New York: Longman.

2013. Menyusun Modul (Bahan Ajar Untuk Persiapan Guru Mengajar). Yogyakarta: Penerbit Gava Media.

Dick, W, Carey. L. Carey. J.O. 2001. The Systematic Design on Instruction. Addison-Wesley Educational Publisher Inc.

Gray, Mel. 2008. Viewing Spirituality in Social Work Through the Lens of Contemporary Social Theory. Australia: British Journal of Social Work.

Khabibah, Siti. (2006). Pengembangan Model pembelajaran Matematika dengan soal Terbuka untuk meningkatkan Kreatifitas siswa sekolah dasar. Disertasi. Tidak dipublikasikan. Surabaya: Program Pasca Sarjana Universitas Negeri Surabaya.

Mujika, Mujamil, Jejem dan Desi. 2014. Pengembangkan Petunjuk Praktikum Larutan Asam Basa Berbasis Inquiry pada Mata Kuliah Praktikum Kimia Dasar II. Sriwijaya : Program Studi Pendidikan Kimia FKIP Universitas Sriwijaya.

Muliawan, Jasa Ungguh. 2014. Metodelogi Penelitian Pendidikan dengan Studi Kasus.Yogyakarta: Gava Media.
Mulyatiningsih, Endang. 2011. Metode Penelitian Terapan Bidang Pendidikan. Bandung: Alfabeta..

Nurgita Rayuni. 2016. Pengembangan Buku Petunjuk Praktikum Kimia Berbasis Green Chemistry untuk SMA/MA kelas XII. Yogyakarta: Jurnal Pendidikan Kimia Volume 1 Nomor 1. Hal: 1.

Nugraho, Alfian. 2015. Pengembangan modul pembelajaran kimia koloid berbasis Problem Based Learning (PBL) dengan orientasi pada Chemo- Inteprenneurship (CEP) pada materi koloid SMA/MA kelas XI. Yogyakarta: Program Studi Pendidikan Kimia Fakultas Sains dan Reakayasa FKIP Sunan Kalijaga Yogyakarta hal :30

Pratiwi, Ni Kadek, Rhedhana, Wayan dan Maryam, Siti.2014.Pengembangan buku Pedoman Praktikum Kimia Ramah Lingkungan untuk Pembelajaran Kimia SMA. Singasara: Jurnal Pendidikan Kimia Vol 2 No. 1 Hal 3.

Purba, Michael. 2003. Kimia 2000 SMU Kelas 1. Jakarta: Erlangga.

Wiwik kartika sari. 2015. Pengembangan Diktat Praktikum Berpendekatan Problem Based Learning (PBL) Untuk Meningkatkan Hasil Belajar Siswa Materi Larutan Penyangga SMA Islam Surdirman Amberawa. Malang. Jurnal FPIMA Kimia. Volume 2 Nomor 1. Hal: 16.

Purnomo, Dwi. Indrowati, Meti dan Karyanto, Puguh. 2013. Pengaruh Penggunaan Modul Hasil Penelitian Pencemaran di Sungan Pepe Surakarta Sebagai Sumber Belajar Biologi Pokok Bahasan Pencemaran Lingkungan Terhadap Hasil Belajar Siswa. Jurnal Pendidikan Biologi Volume 5 Nomor 1 hal 59-69. 